\title{
Ecologization of retail: Russian experience
}

\author{
Ruslan Ikramov ${ }^{*}$ and Gleb Mityashin ${ }^{1}$ \\ ${ }^{1}$ Peter the Great St. Petersburg Polytechnic University, 195251 Saint-Petersburg, Russia
}

\begin{abstract}
The paper analyzes the changes that have occurred in retail trade under the influence of eco-friendly trends in Russia. The paper defines the terms ecologization and ecologization of retail. There are three main directions of retail development: commodity ecologization, greening business processes and ecologization of the consumer environment. The paper presents an analysis of innovations in each of the areas of greening. The main elements of commodity greening are the introduction of ecopackaging into the product range and the introduction of eco-packages. For industrial greening, it is recommended to organize work with suppliers taking into account the need for the turnover of reusable containers and pay special attention to the management of goods with an expiring shelf life. The organization of the collection of secondary raw materials on the territory of stores is considered as the greening of the consumer environment. The paper emphasizes the importance of using eco-friendly innovations in the marketing and advertising strategies of stores. For the analysis, the practice of large Russian retailers, such as "X5 Retail Group", "Magnit", "Lenta", "VkusVill" was used.
\end{abstract}

\section{Introduction}

Changing consumer behaviour patterns lead to development of e-commerce and ecologization of retail. Customers do not want to spend their time in store, they prefer to buy products in Internet. Consumers also want to to ensure that the shopping process meets modern environmental trends. This leads to the fact that the consumer prefers those retail trade enterprises whose activities are more environmentally friendly, and the service model allows you to join the trends of caring for the environment.

Fast growth of e-commerce is covered in detail in both Russian and foreign scientific papers. The authors paid attention to a wide range of issues: from the technological nuances of creating websites to finding a balance between traditional and electronic commerce [14].

Development of green retail in Russia has not been analyzed in the literature to a sufficient extent $[5,6]$. This paper presents an analysis of the decisions of the operators of retail trade enterprises aimed at ensuring compliance with environmental trends.

\footnotetext{
* Corresponding author: $\underline{\mathrm{ikramov} \text { ra@spbstu.ru }}$
} 


\section{Materials and methods}

In this work, mainly general scientific methods of analysis and synthesis of Internet resources and scientific literature were used. The method of case analysis was also widely used in the work.

The structures for performing this work can be represented as the following list:

1.Definitions of the terms ecologization, ecologization of retail, and eco-friendly marketing were formulated.

2. The directions of ecologization of retail were identified.

3. Case studies of the eco-friendly activities of Russian retail chains and individual stores was carried out (table 1). The statistics shown in Table 1 are taken from Internet resources [7-12]

Table 1. Data about the largest Russian retail chains.

\begin{tabular}{|l|c|c|}
\hline $\begin{array}{c}\text { Name of the retail } \\
\text { chain/company }\end{array}$ & Number of stores & $\begin{array}{c}\text { Volume of sales (in } \\
\text { millions of rubles) }\end{array}$ \\
\hline X5 Retail Group & 18948 & 1973.71 \\
\hline Magnit & 20860 & 1510.07 \\
\hline Lenta & 379 & 437.49 \\
\hline VkusVill & 1200 & 114.01 \\
\hline
\end{tabular}

4.In the end, the provisions were formulated that reveal the experience of greening Russian retail.

\section{Results and discussion}

\subsection{The idea and essence of ecologization of retail}

Ecologization - minimization of negative effects on the environment [13-15]. Ecologization of retail is the process of changing the business processes of an organization in order to minimize negative harm to the environment [16]. Eco-friendly marketing - actions to promote the eco-friendly component of a retail trade enterprise, aimed at finding new customers and strengthening the retailer's competitive position [17].

Considering the customer's need for greening means that it is not enough for a retail company to simply offer customers the products that they directly go to the store for - it is necessary to ensure that these products (and, more broadly, the service model as a whole) correspond to the changed values of consumers [18]. Greening can be a special case of social marketing when the emphasis in the marketing policy of the enterprise is on noncommercial elements [19].

In work [20], ecologization of retail is divided into three areas (Fig. 2)

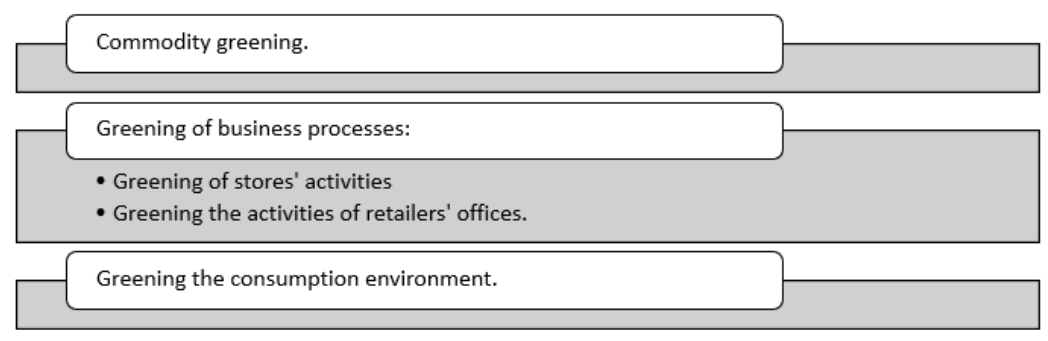

Fig. 2. Directions of ecologization of retail. 
Next, the paper will present the solutions implemented by retailers in each of the areas of greening.

\subsection{Commodity greening}

Commodity greening consists in expanding the supply of eco-friendly products and products in eco-friendly packaging [21].

To implement product greening, many retailers, such as, for example, "Magnit", allocate a separate rack for products for a healthy lifestyle. Retailers also prefer those suppliers who offer products in eco-friendly packaging. Eco-friendly packaging packaging made from more eco-friendly materials or packaging made using an ecofriendlier technology, or packaging that can be recycled, or packaging that can be repeatedly used in the future. Note that the retailer cannot independently promote products in eco-friendly packaging, as they can be presented in any of the product groups. Informing that a particular product is offered in eco-friendly packaging is made by placing information on the packaging that it is eco-friendly. That is, the manufacturer puts information on the packaging that it is produced environmentally friendly. Thus, the manufacturer creates a positive image of its own brand, and the retailer extracts only an indirect effect from the fact that it sells this product.

An important element of commodity greening is the formation of an assortment of shopping bags. More than 10 years ago, single-use plastic bags were offered to customers for free when making a purchase. Back then, it was considered an element of customer care. Then retailers began selling single-use plastic bags for money. This led to a significant increase in profits, as the bags were the best-selling item (a plastic bag was included in every second purchase). Then retailers faced the trend of greening: at the same time, prices for disposable plastic bags were raised, reusable fabric bags and paper disposable bags were added to the range. This decision turned out to be reasonable, which is confirmed by the statistics of sales of eco-packages by "X5 Retail Group", which operates more than 14,000 stores (Fig. 3) [22].

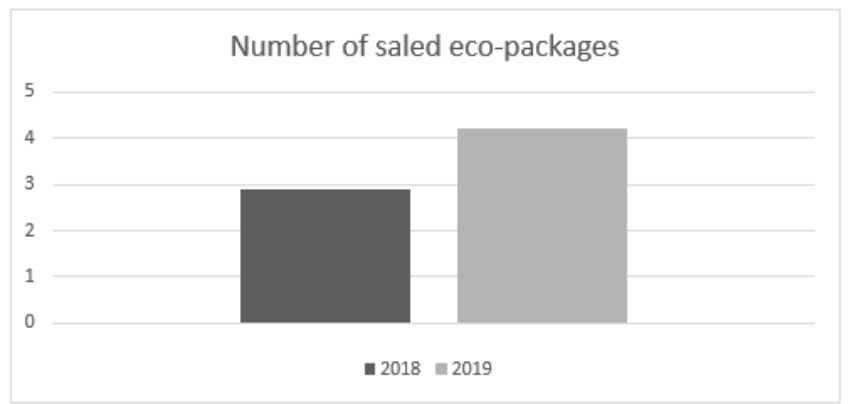

Fig. 3. The number of eco-packages sold by X5 Retail Group.

Figure 3 shows the analyzed years horizontally, and the number of eco - bags sold (paper disposable and reusable), measured in millions, vertically. In 2018, just under 3 million eco packages were sold, while in 2019 this figure increased by more than a million. It should be noted that it is impractical to analyze the data of 2020 , since under the influence of the pandemic, the number of purchases in traditional stores has decreased, and most customers ordered products online with delivery [23].

Thus, commodity greening is only a small part of the greening of retail, it consists in forming an assortment of products in eco-friendly packaging and eco-friendly packages, 
while slogans advertising the importance of caring for the environment are placed on ecopackages.

\subsection{Grening of business processes}

Greening of business processes (or industrial greening) is the greening of processes that are not related to customer service. It is divided into the greening of the activities of stores and the greening of the activities of service offices (the issues of greening distribution centres are not considered in this paper, since the article is devoted to retail trade).

The greening of office activities is primarily associated with a reduction in the amount of waste generated and a reduction in the amount of electricity consumed. "Lenta" is a pioneer in the greening of retail chain offices in Russia. This retailer banned office workers from using disposable plastic dishes and purchased reusable ones at its own expense. Moreover, all the used paper is handed over to the wastepaper. The offices are equipped with inventory for separate waste collection.

Greening of the store's activities is the most difficult element of greening, as it covers a wide range of tasks: from organizing work with suppliers to minimizing waste from the activities of stores [24, 25].

Since greening is primarily associated with minimizing the amount of waste, the greening of the store's activities is focused on reducing the number of goods being written off and packaging being disposed of, as well as on purchasing more environmentally friendly means of production.

Written-off waste should be understood as goods that are not suitable for sale. These include natural loss of goods and goods that have expired. It is almost impossible to reduce the natural loss of goods, since it is impossible to prevent the process of spoilage (natural loss of goods is characteristic of fruits and vegetables stored in bulk). However, there are many options for minimizing products that have expired (Figure 4).

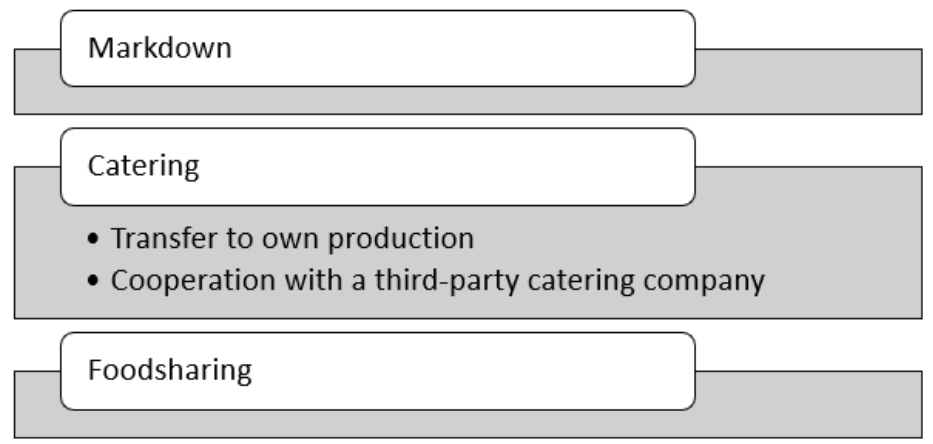

Fig. 4. Options for managing expired products.

Markdown is the provision of a discount to the buyer with a reservation about the need to use the product before its expiration date [26]. This option is advantageous for both parties: the retailer minimizes waste for the disposal of decommissioned goods and receives a small profit from their sale, and the buyer receives a still fresh product with a significant (usually no more than 50\%) discount. This option of managing products with an expiring expiration date is typical for most Russian retailers. Note that the markdown of products with an expiring expiration date is positioned as a discount, but it can be positioned as a tool to minimize waste. In this case, the retailer draws attention to the issue of caring for the environment, because buying a still fresh product at a significant discount is both financially profitable and helps to protect the environment. 
The second option is to involve expired products in the production of culinary products. Expired products can be transferred to the store's own culinary division, if it exists in the store. If not - it makes sense to consider a partnership with a local catering establishment. This option of managing products with an expiring expiration date is complicated by the fact that the number of products with a suitable expiration date is uneven.

Another option for managing expired products is foodsharing. Foodsharing is the practice of distributing expired goods to members of the public. Its development corresponds to the current trend of transition to a shared economy [27-29]. The goal of enterprises and individuals engaged in food-sharing is to prevent the formation of food waste, and to inform the public about the emerging problem [30].

Food-sharing companies are intermediaries who independently collect still usable goods from stores and distribute them to those in need. This model is called B2C (business to client) foodsharing, since there is an intermediary company that provides full service to the food distribution process. At the same time, the store is responsible for the quality of the transferred products.

Note that the actions of the store, as a rule, are free of charge (that is, the transfer of goods with an expiring expiration date is carried out in the format of a donation), however, an obvious financial advantage is to reduce the cost of disposing of spoiled goods. In addition, the retail trade operator receives several intangible benefits:

- Reducing the negative impact on the environment.

- Emphasizing the fact that only fresh and high-quality products are sold.

- Charity.

Even though the practice of food-sharing in Russia is in its infancy, we suppose, cooperation with food-sharing platforms is the most advantageous option for managing products with an expiring shelf life, as it emphasizes the high environmental responsibility of the retailer. Moreover, cooperation with food-sharing platforms enhances the store's advertising campaign, which can emphasize the importance of minimizing waste [31].

In addition to reducing the amount of goods being disposed of, it is important to pay attention to the disposal of packaging materials. It is achieved through a special organization of work with suppliers. Some retailers prescribe in the terms of the contract with suppliers the need for packaging turnover, so they prevent the need for waste generation after receiving each batch of goods [32].

Moreover, retailers are trying to buy more environmentally friendly means of production. For example, "X5 Retail Group" buys stretchers for purchases only from recycled plastic.

It should be noted that the greening of the stores' activities inspired environmentally responsible entrepreneurs to create a new store concept, which was called waste-free [33]. A feature of such stores is the sale of goods exclusively in the packaging of customers. Goods in such stores are stored in bulk, and the buyer himself determines the desired quantity of goods. These stores are the most environmentally friendly, as they produce a minimum of waste, but their concept is hardly ideal, since they offer a very narrow (less than 600 items) range of products, and the buyer must spend a significant amount of time making a purchase [33].

\subsection{Greening the consumption environment}

Greening the consumer environment - creating conditions for minimizing environmental damage when consuming store goods (and other goods). The essence of greening the consumer environment is to provide an opportunity to take care of the environment not only through the purchase of eco-goods. 
To meet this need, the operators of retail stores offer to hand over some types of waste for recycling. For example, "VkusVill" accepts used batteries and small batteries in every store, and several "Lenta" hypermarkets have already installed devices for accepting plastic bottles. These solutions are beneficial for retail operators, as they use them both to promote the eco-friendly component and to make a profit (due to the large volume of recycled raw materials collected, the retailer makes a profit from its sale to specialized companies).

At the same time, some Russian stores have organized the collection of more specific secondary raw materials. For example, in the "B12 Zero Waste" store, which is ideologically waste-free, you can recycle receipts, disposable shaving machines, toothbrushes [34]. It should be noted that this solution is aimed at environmentally responsible citizens, and this store stands out favourably, but it is unprofitable for the enterprise. The loss is formed because these wastes are handed over for processing free of charge, moreover, the store operator pays for their transportation to the place of reception from its own funds.

Thus, Russia currently has some conditions for eco-friendly shopping.

\section{Results}

The completed study allows you to establish the following:

1. Russian retailers are interested in greening the activities of stores.

2.Russians have become more attentive to nature and more environmentally responsible.

3. Works on ecologization of retail are carried out in three main areas: commodity ecologization, industrial ecologization and ecologization of the consumer environment.

4. Greening is a powerful marketing tool that strengthens the store's competitive position.

5. In many cases, eco-friendly solutions are cost-effective (for example, markdown of goods or resale of secondary raw materials).

6. Greening should be used as an advertising tool.

7. Environmental trends have led to the creation of a new concept of stores - waste-free.

\section{References}

1. S. Bozhuk, N. Kozlova, N. Krasnostavskaya, T. Maslova, IOP Conf. Ser.: Mater. Sci. Eng., 497, 012114 (2019) DOI: 10.1088/1757-899X/497/1/012114

2. I. Kapustina, T. Pereverzeva, T. Stepanova, IOP Conf. Ser.: Mater. Sci. Eng., 497, 012120 (2019) DOI: 10.1088/1757-899X/497/1/012120

3. W. Michalak, L. Calder, Progress in Planning, 60, 111-126 (2003) DOI:10.1016/S0305-9006(02)00094-6

4. G. Wagner, H. Schramm-Klein, S. Steinmann, Journal of Business Research, 107, 257270 (2020) DOI: 10.1016/j.jbusres.2018.10.048

5. L.A. Zazykina, A.A. Bukova, IOP Conf. Ser.: Earth. Environ., 650, 012018 (2021) DOI:10.1088/1755-1315/650/1/012018

6. M. De Silva, P. Wang, A. Kuah, Journal of Business Research, 122, 712-724 (2021) https://doi.org/10.1016/j.jbusres.2020.01.016

7. Net revenue of the largest Russian retailers // marketing.rbc.ru [Electronic resource] URL: https://marketing.rbc.ru/articles/12185/\#: :text=3а\%20прошедший\%20год\%2 0X5\%20Retail,роста\%20среднего\%20чека\%20на\%2012\%25 (date of visit: 24.05.2021) 
8. Net revenue of "VkusVill" // retailer.ru [Electronic resource] URL:

https://retailer.ru/vkusvill-opublikoval-finansovyj-otchet-po-itogam-2020-goda/ (date of visit: 24.05.2021)

9. "X5 Retail Group" number of stores // vk.com [Electronic resource] URL: https://vk.com/x5retailgroup (date of visit: 24.05.2021)

10. "Magnit" number of stores // www.rbc.ru [Electronic resource] URL:

https:/www.rbc.ru/business/29/04/2020/5ea91dca9a794704230029fl\#: :text=«Магни т»\%20управляет\%20одноименными\%20магазинами\%20y,в\%203\%20718\%20н аселенных\%20пунктах (date of visit: 24.05.2021)

11. "Lenta" number of stores // lenta.com [Electronic resource] URL: https://lenta.com/okompanii/ (date of visit: 24.05.2021)

12. "VkusVill" number of stores // www.forbes.ru [Electronic resource] URL: https://www.forbes.ru/profile/409303vkusvill\#: :text=К\%20концу\%202019\%20года\%20количество,года\%20«ВкусВи лл»\%20впервые\%20выплатил\%20дивиденды (date of visit: 24.05.2021)

13. V.V. Bakharev, I.V. Kapustina, G.Yu. Mityashin, Yu.V. Katrashova, Siberian Journal of Life Sciences and Agriculture, 12 (5), 79-96 (2020) DOI:10.12731/2658-6649-202012-5-79-96

14. Y.V. Vertakova, V.A. Plotnikov, IOP Conf. Ser.: Earth Environ., 392, 012078 (2019) DOI: $10.1088 / 1755-1315 / 392 / 1 / 012078$

15. E.Borkova, V. Plotnikov, L. Vatlina, R. Shakhnovich, Vision 2020: Sustainable Economic Development and Application of Innovation Management, 7394-7401 (2019) DOI:10.1108/IJRDM-02-2013-0042

16. P. Kumar, International Journal of Retail \& Distribution Management, 42 (7), 613-625 (2014) DOI:10.1108/IJRDM-02-2013-0042

17. D.C. Dabija, C.M. Pop, Environmental Engineering and Management Journal, 12(2), 393-400 (2013)

18. I.D. Kotliarov, Marketing and marketing research, 4, 244-254 (2017)

19. O.M. Kulikova, S.D. Suvorova, Modern science: actual problems of theory and practice. Series: Economics and law, 2, 31-35 (2017)

20. G. Yu. Mityashin, Yu.V. Katrashova, Yu. B. Mindlin, Modern science: actual problems of theory and practice. Series: Economics and law, 1, 50-55 (2021) DOI: 10.37882/2223-2974.2021.01.17

21. N.A. Kozlova, S.I. Golovkina, A.P. Kushniruk, Vestnik Nacional'noj akademii turizma, 2(42), 82-85 (2017)

22. Reducing the number of packages sold // www.gazeta.ru [Electronic resource] URL: https://www.gazeta.ru/business/2020/01/22/12921986.shtml (date of visit: 22.05.2021)

23. E.F. Melikova, A.N. Burmistrov, K.B. Kostin, A.A. Semenova, Prakticheskij marketing, 12 (286), 3-12 (2020)

24. A. Hallorana, J. Clementc, N. Kornumc, C. Bucatariud, J. Magid, Food Policy, 49 (1), 294-301 (2014) DOI: https://doi.org/10.1016/j.foodpol.2014.09.005

25. S. Sumrin, S. Gupta, Y. Asaad, Y. Wang, S. Bhattacharya, P. Foroudi, Journal of business research, 122, 627-639 (2021) DOI: 10.1016/j.jbusres.2020.08.001

26. V.V. Bakharev, G.Yu. Mityashin, Economic vector, 1(24), 50-56 (2021) DOI: 10.36807/2411-7269-2021-1-24-50-56

27. B.Zh. Tagarov, ECO, 7, 140-155 (2019) 
28. E.V. Popov, A.Yu. Veretennikova, A.A. Safronova, Society and economy, 4, 25-37 (2020)

29. S.Y. Barykin, I.V. Kapustina, T.V. Kirillova, V.K. Yadykin, Y.A.Konnikov, Journal of Open Innovation: Technology, Market, and Complexity, 6(4), 1-16. (2020) DOI: 10.3390/joitmc6040152

30. Foodsharing // foodsharing.ru [Electronic resource] URL: https://foodsharing.ru/ (date of visit: 22.05.2021)

31. I. Krasyuk, T. Kirillova, E. Nazarova, G. Dudakov, I. Moshkin, IOP Conf. Ser.: Mater. Sci. Eng., 940, 012056 (2020) DOI:10.1088/1757-899X/940/1/012055

32. K. Petljak, K. Zulauf, I. Štulec, S. Seuring S, R. Wagner, Supply Chain Management 23 (1), 1-15 (2018) DOI:10.1108/SCM-04-2017-0133

33. G.Yu. Mityashin, Yu.V. Katrashova, V.V Bakharev, I.V. Kapustina, Economic vector, 4(23), 82-88 (2020) DOI: 10.36807/2411-7269-2020-4-23-82-88

34. B12 Zero Waste// vk.com [Electronic resource] URL: https://vk.com/topic169648618_41506619 (date of visit: 24.05.2021) 